\title{
Holism and sexual function: the difference between sex and atoms
}

\author{
Stefan Mohr • Annette Kuhn
}

Published online: 2 September 2011

(C) The International Urogynecological Association 2011

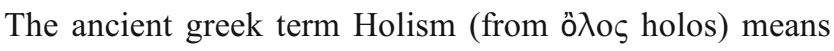
all, whole, entire, total. The term holism in its narrower sense describes the idea that all the properties of a given system (scientific, physical, social, economic, aesthetic, linguistic, etc.) cannot be determined or explained by its component parts alone. Instead, the system as a whole determines in an important way how the parts behave and the whole of a system is always greater than the sum of its parts.

If we look at urogynecologic studies involving sexual function, we find only few that involve social circumstances, comorbidities or general medications [1, 2]. Furthermore, the focus is laid on the women's sexual function, thus ignoring the sexual well-being of their significant others.

Social scientist and physician Nicholas A. Christakis explains that "for the last few centuries, the Cartesian project in science has been to break matter down into ever smaller bits, in the pursuit of understanding. This works to some extent; however, putting things back together in order to understand them is harder, and typically comes later in the development of a scientist or in the development of science."[3]

As cited above, the scientific trend towards breaking every kind of system down into its elementary units for a

\footnotetext{
S. Mohr $(\bowtie) \cdot$ A. Kuhn

Department of Obstetrics and Gynecology, Urogynecology, Inselspital, Bern University Hospital, University of Bern, Effingerstrasse 102, 3010 Bern, Switzerland e-mail: s.mohr@gmx.ch
}

better understanding of the whole works well in some domains. This trend is going back to René Descartes' (1596-1650) dualism, which pleaded for a separation between body and mind. The idea was further developed, resulting in today's reductionism or atomism with the assumption that all systems are made up of ultimate, indivisible parts [4]. We can understand matter by breaking it down to atoms, then protons, electrons and neutrons, quarks, gluons, and so on. In the same way we can understand organisms by breaking them down into organs, then tissues, cells, organelles, proteins, DNA, etc. Likewise, in human medicine the growing knowledge takes its toll as the incremental specialization breaks the patient down into separate components.

However, analyzing sexual function we will have to understand sexuality as a holistic system. How can female sexual function improve if-for whatever reason-the sexual function of the partner deteriorates [5]? Holism is an appreciation not of the simple, but of the complex, or at least of the simplicity and coherence in complex findings. Moreover, unlike curiosity or empiricism, holism takes a while to acquire and to appreciate. It is a very grown-up disposition.

For the determination of clinical sexual function, atomism does not really make sense. In studies, we should address the sexual function of our patients and of their partners, probably take social influences and comorbidities into consideration and not concentrate on one single issue.

The scientific concept that would enrich everyone's cognitive toolkit is holism: The abiding recognition that holistic sexual function, involving the sexual function of 
the patients and of their partners, has properties not present in the parts and not reducible to the study of the parts.

\section{References}

1. De Souza A, Dwyer P, Rosamilia A, Hiscock R, Lim Y, Murray C, Thomas E, Conway C, Schierlitz L. Sexual function following retropubic TVT and transobturator Monarc sling in women with intrinsic sphincter deficiency: a multicentre prospective study. Int Urogynecol J Pelvic Floor Dysfunct doi:10.1007/s00192-011-1461-9

2. Khandwala S, Jayachandran C (2011) Transvaginal mesh surgery for pelvic organ prolapse-Prolift+M: a prospective clinical trial. Int Urogynecol J Pelvic Floor Dysfunct. doi:10.1007/s00192-011$1482-4$

3. Christakis NA, Fowler JH (2009) The surprising power of our social networks and how they shape our lives

4. Ackoff RL (1974) Redesigning the future; a systems approach to societal problems

5. Mohr S, Kuhn P, Mueller MD, Kuhn A (2011) Painful love"hispareunia" after sling erosion of the female partner. J Sex Med 8:1740-1746 